\title{
Effect of detasseling on baby corn, green ear and grain yield of two maize hybrids
}

\author{
Joserlan N Moreira ${ }^{1}$; Paulo Sérgio L Silva ${ }^{1}$; Kathia MB Silva ${ }^{2}$; Jeferson LD Dombroski ${ }^{1}$; Renato S Castro ${ }^{1}$ \\ ${ }^{1}$ UFERSA, C. Postal 137, 59625-900 Mossoró-RN; 2UERN, C. Postal 70, 59610-090 Mossoró-RN; paulosergio@ufersa.edu.br
}

\begin{abstract}
Three experiments (E1, E2, and E3) were carried out in Mossoró, Brazil, to evaluate baby corn yield, green ear yield, and grain yield, respectively, of two corn hybrids (AG 1051 and BRS 2020), in response to detasseling (with or without tassel). A randomized splitplot block design (with hybrids defined as plots) and ten replicates was used. The three experiments were planted on the same day and in neighboring areas. In the three experiments, the hybrids did not differ from each other on the dry matter mass and number of tassel branches. In E1 (baby corn production at 180 thousand plants ha' ${ }^{-1}$ ), for both hybrids, the following effects were observed due to detasseling: a) an increase in ear total number, in ear total weight, in marketable unhusked ears number and in marketable unhusked ears weight; b) no change was observed in the number and weight of marketable husked ears. Hybrid AG 1051 was superior to BRS 2020 for weight of marketable husked ears, but the two hybrids did not differ in other traits utilized to evaluate baby corn yield. In E2 (green ear yield at 50 thousand plants $\mathrm{ha}^{-1}$ ), detasseling did not change the following traits in both hybrids: total number and weight of ears; number and weight of marketable unhusked ears and marketable husked ear weight. Detasseling reduced the number of marketable husked ears in cultivar AG 1051, but not in BRS 2020. The two hybrids did not differ in total number of ears and number of marketable unhusked ears. Hybrid AG 1051 was superior to BRS 2020 in regard to the total ears weight, marketable unhusked ears weight and number and weight of marketable husked ears. In E3 (grain yield at 50 thousand plants $\mathrm{ha}^{-1}$ ), detasseling did not affect grain yield (RG) and hybrid AG 1051 was superior to BRS 2020 for grain yield.
\end{abstract}

Keywords: Zea mays L., cultivars, tassel.

\section{RESUMO}

Efeito do despendoamento sobre os rendimentos de minimilho, de espigas verdes e de grãos de dois híbridos de milho

Três experimentos (E1, E2 e E3) foram realizados em Mossoró$\mathrm{RN}$ com o objetivo de se avaliar, respectivamente, os rendimentos de minimilho, de espigas verdes e de grãos de dois híbridos de milho (AG 1051 e BRS 2020), em resposta ao despendoamento (com e sem pendão). O delineamento experimental foi de blocos casualizados com parcelas subdivididas (cultivares nas parcelas) e dez repetições. Os três experimentos foram plantados no mesmo dia e em áreas vizinhas. Os híbridos não diferiram, nos três experimentos, quanto à massa da matéria seca e quanto ao número de ramificações do pendão. Em E1 (produção de minimilho na densidade de 180 mil plantas ha ${ }^{-1}$ ), em ambos os híbridos, os seguintes efeitos foram observados devido ao despendoamento: um aumento no número e peso totais de espigas e no número e peso de espigas empalhadas comercializáveis; b) nenhuma mudança foi observada no número e peso de espigas despalhadas comercializáveis. O híbrido AG 1051 foi superior ao híbrido BRS 2020 quanto ao peso de espigas despalhadas comercializáveis, mas os dois híbridos não diferiram quanto às outras características utilizadas para avaliar o rendimento de minimilho. Em E2 (produção de espigas verdes na densidade de 50 mil plantas ha ${ }^{-1}$ ), o despendoamento não alterou as seguintes características em ambos os híbridos: números e pesos totais de espigas e de espigas empalhadas comercializáveis, e peso de espigas despalhadas comercializáveis. O despendoamento reduziu o número de espigas despalhadas comercializáveis no híbrido AG 1051, mas não em BRS 2020. Os híbridos não diferiram quanto aos números total e de espigas verdes empalhadas comercializáveis. O híbrido AG 1051 foi superior ao BRS 2020 quanto aos pesos total e de espigas empalhadas comercializáveis e quanto ao número e peso de espigas despalhadas comercializáveis. Em E3 (produção de grãos na densidade de 50 mil plantas ha $^{-1}$ ), o despendoamento não afetou o rendimento de grãos e o híbrido AG 1051 foi superior quanto ao RG.

Palavras-chave: Zea mays L., cultivares, pendão.

(Recebido para publicação em 14 de maio de 2009; aceito em 2 de setembro de 2010) (Received on May 14, 2009; accepted on September 2, 2010)

$\mathrm{M}$ aize is a monoecious plant, with staminate flowers born on an apical inflorescence (tassel) and with pistilated flowers produced on one or more lateral branches, which develop into grain-bearing rachises (ears). In both tassel and ear flowers, a pair of stamens arises opposite the lemmas and a third stamen initiates later at right angles to the first pair but from a point on the meristem below its insertion. Gynoecia develops on both tassel and ear flowers first as a ridge which overgrows the apical meristem giving rise to the stylar canal and the elongated silk. Male flowers arise in the tassel through selective vacuolation and abortion of the cells of the early gynoecium. The single female flower in each ear spikelet arises through the vacuolation and abortion of stamens in the upper flower and the repression of growth of and eventual regression of the lower flower in each spikelet (Cheng et al., 1983). The similarities in growth between ear and tassel primordial lend further support to the hypothesis that both the maize tassel and ear are derived from a common inflorescence pattern (Sundberg \& Orr, 1996). The tassel is differentiated first and has developmental priority over the ears (Cheng \& Paredy, 1994). 
Baby corn, also known locally as minimilho, is the name given to young corn ears (Galinat \& Lin, 1998), harvested right after silk emergence, and consumed fresh or as preserves. Baby corn production is a profitable market (Hardoim et al., 2002), and provides diversification, added value, and increased income (Pandey et al., 2002).

Green kernels constitute the socalled green corn, i.e., grain in the milky stage, with 70 to $80 \%$ moisture. Green corn is a product highly appreciated by Brazilians, and is also used in the preparation of typical dishes. Dry grains are harvested with moisture around 20\% and are used as human and animal foods. After harvesting the green and dry ears, the stove is used to feed the grower's own herds or otherwise sold (Silva et al., 2003).

Detasseling consists of removing the tassels before pollen is released. Apparently, greater interest in corn detasseling began in the last decades of the nineteenth century (Geraldi et al., 1985), when the first attempts were initiated to produce hybrid corn cultivars. The interest in studying the influence of detasseling on corn performance persists to date (Komatuda et al., 2006; Sangoi et al., 2006). For almost 120 years during which corn detasseling studies have been conducted, most of those studies aimed to evaluate the effects of this practice on mature grain yield. Such studies, including older ones (Grogan, 1956, for example) and more recent investigations (Sangoi et al., 2006, for example) have shown that detasseling may influence grain yield positively or negatively, or have no influence at all. The first papers about detasseling effects on baby corn yield found in the consulted literature date from the last decade of the twentieth century (Aekatasanawan et al., 1994). Detasseling is important for baby corn production due to the fact that the product is useless for the market when kernels are formed and detasseling prevents kernel formation. These papers, similarly as those on grain yield, indicated that detasseling may have either positive (Aekatasanawan et al., 1994) or negative effects (Pereira Filho et al., 2005) on baby corn yield.
The positive or negative effects of detasseling on grain yield (Grogan, 1956; Sangoi et al., 2006) and baby corn yield (Aekatasanawan et al., 1994; Pereira Filho et al., 2005) were dependent upon genotypic and environmental factors. No papers dealing with the effects of detasseling on green ear yield were found in the consulted literature.

The objective of this investigation was to evaluate baby corn, green ear, and grain yield of two corn hybrids as a response to detasseling.

\section{MATERIAL AND METHODS}

Three experiments were conducted, hereinafter identified as experiments 1 , 2 , and 3. In each of them, assessments were done for baby corn yield, green corn yield, and grain yield, respectively. The experiments were planted in neighboring areas and on the same day, at Fazenda Experimental "Rafael Fernandes". This farm is located in the district of Alagoinha, $20 \mathrm{~km}$ away from the municipal seat of Mossoró-RN ( $5^{\circ}$ $11^{\prime} \mathrm{S}, 37^{\circ} 20^{\prime} \mathrm{W}, 18 \mathrm{~m}$ elevation). The soil in the experimental area is a "RedYellow Eutrophic Argisol" (according to the Brazilian Soil Classification System-Embrapa, 1999), or a Ferric Lixisol, according to the Soil Map of the World (FAO, 1988). Soil analysis of a $0-20 \mathrm{~cm}$ sample indicated: $\mathrm{pH}$ $\left(\mathrm{H}_{2} \mathrm{O}\right)=6.2 ; \mathrm{Ca}=5.2 ; \mathrm{Mg}=1.5 ; \mathrm{K}=$ $0.33 ; \mathrm{Na}=0.18 ; \mathrm{Al}=0.00 ; \mathrm{H}+\mathrm{Al}=$ $0.49 ; \mathrm{CEC}=3.02$; and $\mathrm{t}=2.53 \mathrm{cmol}_{\mathrm{c}}$ $\mathrm{dm}^{-3} ; \mathrm{m}=0.00 \% ; \mathrm{V}=83.8 \% ; \mathrm{P}=2.0$ $\mathrm{mg} \mathrm{dm}{ }^{-3} ; \mathrm{C}=0.48 \%$; organic matter $=$ $1.14 \mathrm{~g} \mathrm{~kg}^{-1}$. Other characteristics of the experimental soil are presented by Mota (2004). In the three experiments, the soil was tilled by two cross harrowings and received $30 \mathrm{~kg} \mathrm{~N}, 60 \mathrm{~kg} \mathrm{P}_{2} \mathrm{O}_{5}$, and $30 \mathrm{~kg} \mathrm{~K}_{2} \mathrm{O}$ per ha as planting fertilization. Ammonium sulfate, single superphosphate, and potassium chloride were applied as sources of $\mathrm{N}, \mathrm{P}_{2} \mathrm{O}_{5}$, and $\mathrm{K}_{2} \mathrm{O}$, respectively. The remainder of the $\mathrm{N}$ was applied in two identical plots as sidedressing, at 20 and 40 days after planting, at weeding time. The corn was planted manually on $08 / 04 / 06$, using two seeds per pit in experiment E1, at a spacing of $0.80 \mathrm{~m} \times 0.07 \mathrm{~m}$. In the other experiments, four seeds were used per pit at a spacing of $1.0 \mathrm{~m} \times 0.4$ $\mathrm{m}$. A thinning operation was performed 20 days after planting, leaving the most vigorous plants in each pit (one plant in experiment $\mathrm{E} 1$ and two plants in the other experiments). Therefore, after thinning the experiments had programmed population densities of 180 thousand plants ha-1 (E1) and 50 thousand plants ha $^{-1}$ (E2 and E3). Pest control was done by means of two Deltamethrin sprays $\left(5 \mathrm{~g}\right.$ a.i. ha $\left.{ }^{-1}\right)\left[\right.$ Decis $\left.^{\circledR} 25 \mathrm{EC}\right]$, performed at 7 and 14 days after planting. Weed control was achieved by hoeing (at 20 and 40 days after planting); after each hoeing, the experiment was fertilized with $20 \mathrm{~kg} \mathrm{~N} \mathrm{ha}^{-1}$ (ammonium sulfate). The experiment was sprinkler-irrigated, with experimental plots arranged in a parallel fashion with respect to the row of sprinklers. The water depth required for corn $(5.6 \mathrm{~mm})$ was calculated considering an effective depth of the root system of $0.40 \mathrm{~m}$. Irrigation time was based on water extracted from the soil at a tension of $0.40 \mathrm{Mpa}$. An irrigation shift of 1 day was established. The irrigations started after planting and were suspended one day before each harvest.

Hybrids AG 1051 and BRS 2020 were evaluated with or without tassel removal. Cultivar AG 1051 is a double cross hybrid, with yellow kernels, and was developed for the production of green ears, grain, and silage. Cultivar BRS 2020 is also a double cross hybrid, with semiflint, orange grain and was developed for grain and silage. Detasseling was done at the end of phenological stage three (Fancelli \& Dourado Neto, 1997), from 53 to 63 days after sowing, using pruning shears; tassels were removed by cutting above the flag leaf insertion point. The size of removed tassels was evaluated by dry matter mass and by the number of ramifications. In order to estimate dry mass, a sample weighing about $500 \mathrm{~g}$ was placed in a forced air circulation oven set at $75^{\circ} \mathrm{C}$ until constant weight was achieved. A split-plot completely randomized block design with ten replicates was used, with hybrids assigned to plots and level of detasseling in the sub-plots. Each subplot consisted of three $6.0 \mathrm{~m}$-long rows. The used plot 
area was the central row, from which the plants from one pit at each end were eliminated.

The baby corn was harvested at different times, two to three days after ear silk emergence. Data were collected for number and total weight of ears; number and weight of marketable ears, either unhusked or husked. The total number and weight of ears were estimated based on the total number of ears harvested from the used area. Marketable unhusked ears were considered those free from damage caused by pests or diseases, and marketable husked ears were those with good health showing a color varying from pearly white to light yellow, cylindrical in shape, with a diameter ranging from 0.8 to $1.8 \mathrm{~cm}$ and length ranging from 4 to $12 \mathrm{~cm}$.

The green corn was harvested when the grain moisture content was between 70 and $80 \%$. Evaluations were done for the total number and weight of green ears; number and weight of marketable green ears, either unhusked or husked. The total number and weight of ears were estimated based on the total number of ears harvested from the used plot area of the plot. Marketable unhusked ears were considered those free from damage caused by pests or diseases and with a length of $22 \mathrm{~cm}$ or longer, while husked ears were those with good health and grain set, presenting a length of $17 \mathrm{~cm}$ or longer.

Dry corn was harvested when grain moisture content was close to $20 \%$. Measurements were done for number of ears ha ${ }^{-1}$ (based on ears harvested from the usable area of the plot), number of kernels per ear (obtained from 15 randomly selected ears), grain yield (corrected for a $15.5 \%$ moisture content, wet basis), and 100-kernel weight (estimated based on five 100kernel samples).

The data were analysed using the SAEG software, developed by Universidade Federal de Viçosa (Ribeiro Júnior, 2001), and means were compared using Tukey's test at 5\% probability.

\section{RESULTS AND DISCUSSION}

The baby corn was harvested from days 54 to 68 after seeding, in seven harvests. The green corn was harvested in the period from day 73 to 77 after planting, in three harvests, while dry corn was harvested at 115 days after planting.

HybridAG 1051 was more productive in marketable husked ear weight, surpassing BRS 2020 by $18 \%$, but did not differ from BRS 2020 with regard to the other traits employed to evaluate baby corn yield (Table 1). Marketable husked ear weight is considered the most important trait for baby corn production. Besides, according to the evaluation criteria adopted for baby corn yield determination, cultivars may respond differently (Almeida et al., 2005). Detasseled plants had higher total weight and numbers of baby corn ears, as well as weight and numbers of marketable unhusked baby corn ears than plants with intact tassels (Table 1). The benefits of detasseling on most traits used to evaluate baby corn yield can be explained in a similar manner as those used to explain the positive effects of detasseling on grain yield. Until the 1960's (Duncan et al., 1967) these effects were explained by a reduction in the competition for photoassimilates and nutrients between developing male and female inflorescences, which would positively influence ear formation (Grogan, 1956; Mostut \& Marais, 1982). In the present work, as well as in other papers (Grogan, 1956; Hunter et al., 1969), the tassels were removed after emergence, before pollen was released. However, in those studies, not always detasseling had a positive effect on grain yield. By the way, not even when the tassels were removed before full flag leaf emergence (Sangoi et al., 2006) was the effect on grain yield always positive. When tassels are removed (even before emergence) they are almost or completely formed, so that competition between them and female inflorescences for carbohydrates and nutrients should have already occurred.

The positive effects of detasseling on grain yield observed by other authors, and baby corn yield, as observed in this and other studies, could mostly be caused by apical dominance and a reduction in shading in the upper portions of the plants, as demonstrated by Duncan et al. (1967).

Apical dominance refers to the

Table 1. Number and weight ( $\mathrm{kg} / \mathrm{ha}$ ) for total ear yield, marketable unhusked ears and markeatable husked ears for baby corn production in two maize hybrids in response to detasseling (número e peso totais de espigas e número e peso de espigas comercializáveis, empalhadas e despalhadas, de minimilho de dois híbridos de milho em resposta ao despendoamento), Mossoró, UFERSA, 2006,

\begin{tabular}{|c|c|c|c|c|c|c|}
\hline \multirow{2}{*}{ Treatments $^{1}$} & \multicolumn{2}{|c|}{ Total ears ha ha $^{-1}$} & \multicolumn{2}{|c|}{ Marketable unhusked ears ha $^{-1}$} & \multicolumn{2}{|c|}{ Marketable husked ears ha $^{-1}$} \\
\hline & Number & Weight (kg) & Number & Weight (kg) & Number & Weight (kg) \\
\hline Hybrids & \multicolumn{6}{|c|}{ Hybrid effects } \\
\hline AG 1051 & $250,274 \mathrm{a}$ & $10,548 \mathrm{a}$ & $248,130 \mathrm{a}$ & $10,549 \mathrm{a}$ & $228,725 \mathrm{a}$ & $2,217 \mathrm{a}$ \\
\hline BRS 2020 & $254,203 \mathrm{a}$ & $11,108 \mathrm{a}$ & $253,611 \mathrm{a}$ & $11,102 \mathrm{a}$ & $215,321 \mathrm{a}$ & $1,829 \mathrm{~b}$ \\
\hline CV plots (\%) & 14.85 & 17.85 & 16.13 & 17.86 & 13.72 & 12.34 \\
\hline Detasseling & \multicolumn{6}{|c|}{ Detasseling effects } \\
\hline Yes & $267,751 \mathrm{a}$ & $11,760 \mathrm{a}$ & $265,753 \mathrm{a}$ & $11,754 \mathrm{a}$ & $233,861 \mathrm{a}$ & $2,138 \mathrm{a}$ \\
\hline No & $236,726 \mathrm{~b}$ & $9,897 \mathrm{~b}$ & $235,988 \mathrm{~b}$ & $9,897 \mathrm{~b}$ & $210,185 \mathrm{a}$ & $1,908 \mathrm{a}$ \\
\hline CV subplots $(\%)$ & 17.50 & 21.23 & 17.85 & 21.27 & 18.43 & 20.55 \\
\hline
\end{tabular}

${ }^{1}$ In each treatment group, means followed by the same letter do not differ at $5 \%$ probability by Tukey's test (em cada grupo de tratamentos, médias seguidas pela mesma letra não diferem entre si, a 5\% de probabilidade, pelo teste de Tukey), 
Table 2. Means (ten replicates) of two maize hybrids (for plots with or without tassels) for the traits: total number and weight of green ears; number and weight of marketable unhusked ears; marketable husked green ear [médias (dez repetições) de dois híbridos de milho (para parcelas com ou sem pendões) para as características: número e peso totais de espigas verdes; número e peso de espigas verdes comercializáveis, empalhadas e despalhadas]. Mossoró, UFERSA, 2006.

\begin{tabular}{|c|c|c|c|c|c|c|c|}
\hline \multirow{3}{*}{ Hybrids $^{1}$} & \multirow{2}{*}{\multicolumn{2}{|c|}{ Total ears ha' }} & \multirow{2}{*}{\multicolumn{2}{|c|}{ Marketable unhusked ears ha' }} & \multicolumn{3}{|c|}{ Marketable husked ears ha ${ }^{-1}$} \\
\hline & & & & & \multirow{2}{*}{$\begin{array}{c}\text { Weight } \\
\text { (kg) }\end{array}$} & \multicolumn{2}{|c|}{ Detasseling $\left(\mathrm{n}^{0}\right)$} \\
\hline & Number & Weight (kg) & Number & Weight (kg) & & No & Yes \\
\hline AG 1051 & $57,970 \mathrm{a}$ & $18,324 \mathrm{a}$ & $50,250 \mathrm{a}$ & $17,512 \mathrm{a}$ & $10,104 \mathrm{a}$ & 45,819 a $\mathrm{A}$ & 41,638 a B \\
\hline BRS 2020 & $60,322 \mathrm{a}$ & $15,328 \mathrm{~b}$ & $51,439 \mathrm{a}$ & $14,395 \mathrm{~b}$ & $6,116 \mathrm{~b}$ & $31,701 \mathrm{~b} \mathrm{~A}$ & $34,399 \mathrm{~b} \mathrm{~A}$ \\
\hline CV plots (\%) & 10.83 & 10.39 & 7.64 & 10.55 & 14.62 & 12 & \\
\hline CV subplots $(\%)$ & 9.85 & 10.20 & 9.08 & 10.26 & 13.20 & 9.2 & \\
\hline
\end{tabular}

${ }^{1}$ Means followed by the same lower case letter in the column, and upper case letter in the row are not different from each other by Tukey's test at 5\% probability (médias seguidas pela mesma letra minúscula, na coluna, e pela mesma letra maiúscula, na linha, não diferem entre si, a $5 \%$ de probabilidade, pelo teste de Tukey).

Table 3. Means (of ten replicates and of plots containing plants with or without tassel) of grain yield and its components, of two corn hybrids [médias (de dez repetições e de parcelas contendo plantas com ou sem pendão) do rendimento de grãos e seus componentes, de dois híbridos de milho]. Mossoró, UFERSA, 2006.

\begin{tabular}{lcccc}
\hline Hybrids & $\begin{array}{c}\text { Grain yield } \\
\left.\text { (kg ha-1 }^{-1}\right)\end{array}$ & $\begin{array}{c}\text { Number of } \\
\text { ears ha }^{-1}\end{array}$ & $\begin{array}{c}\text { Number of } \\
\text { kernels ear }^{-1}\end{array}$ & $\begin{array}{c}\text { 100-grain } \\
\text { weight (g) }\end{array}$ \\
\hline AG 1051 & $10,048 \mathrm{a}$ & $49,471 \mathrm{a}$ & $535.55 \mathrm{a}$ & $35.61 \mathrm{~b}$ \\
BRS 2020 & $6,899 \mathrm{~b}$ & $50,111 \mathrm{a}$ & $416.15 \mathrm{~b}$ & $38.14 \mathrm{a}$ \\
\hline CV plots (\%) & 15.99 & 9.31 & 6.44 & 1.71 \\
\hline CV subplots (\%) & 11.62 & 8.18 & 12.48 & 1.38 \\
\hline
\end{tabular}

${ }^{1}$ In each trait, means followed by the same letter do not differ from each other at $5 \%$ probability by Tukey's test (em cada característica, médias seguidas pela mesma letra não diferem entre si, a 5\% de probabilidade, pelo teste de Tukey).

control exerted by the apical shoot on the growth of axillary buds (Cline 1997) and is related to hormonal influence (Dun et al., 2006). It has been postulated that the number of ears per plant is determined by endogenous plant growth regulators, mainly through apical dominance and by competition between ears for nutrients and photoassimilates (Pinthus \& Belcher, 1994). Among the many factors interacting on these processes, the hormonal and nutritional aspects are the most important (García, 1991). Sucrose application resulted in the best ear growth and development of a prolific and a nonprolific hybrid. Ear lengths from the first and second nodes of both hybrids were further increased by the addition of citokinin and auxin. Ear development was also increased by these treatments, compared with the control without hormones (Leal-León et al., 2002). On the other hand, transgenic studies provide molecular evidence of the involvement hypothesis, it has been observed (Hunter et al., 1969) that the removal of tassel branches also increased grain yield in corn. It probably makes more sense to consider both hypotheses as true, but one being more important than the other, depending on genotypic and environmental factors.

Hybrid AG 1051 was superior to the other hybrid with regard to the weights of the three ear classes evaluated: total and marketable, unhusked and husked (Table 3). Detasseling had a negative effect on the number of marketable husked green ears in hybrid AG 1051, but did not influence the other hybrid, indicating an effect of the hybrids $x$ "tassel-related treatments" interaction. Differences between hybrids with regard to traits for green corn yield evaluation have been also observed by other authors (Silva et al., 1998; Almeida et al., 2005). Although many studies have demonstrated beneficial effects of detasseling on baby corn (Carvalho et al., 2002) and grain yield (Sangoi et al., 2006), negative detasseling effects on baby corn (Pereira Filho et al., 2005) and grain yield (Sangoi et al., 2006) were also found, such as this work's findings with respect to the number of marketable husked green ears in cultivar AG 1051 (Table 4). Detasseling could cause plant damage and may have more or less serious negative consequences on fruit yield, depending on the cultivars and environmental conditions. Such damage could translate into physiological problems (like wound healing, for example) and facilitated attacks by diseases (Grogan, 1956) and 
pests. In other words, under certain conditions detasseling can be beneficial, but it can occasionally compromise plant yield.

There was no effect of detasseling on grain yield and its components, but hybrid AG 1051 was superior to cultivar BRS 2020 with respect to grain yield (Table 5). This superiority was due to the higher number of kernels ear ${ }^{-1}$ in cultivar AG 1051, which may have compensated its lower 100-kernel weight.

In the three experiments, there were no differences between hybrids with regard to tassel dry mass and number of tassel branches. The means obtained for these traits in the three experiments were: in hybrid AG 1051, $0.53 \mathrm{~g}$ tassel $^{-1}$ and 11.90 ramifications tassel- $^{-1}$, respectively; in hybrid BRS 2020, the corresponding values were $0.47 \mathrm{~g}$ and 12.60 ramifications tassel $^{-1}$. Therefore, even having same-size tassels, hybrids may respond differently to detasseling, at least for some traits.

Although different experiments were carried out, the fact that they were planted on the same day and in neighboring areas allows pairwise comparisons. Detasseling was beneficial for most traits employed to evaluate baby corn yield in both hybrids; it negatively influenced green ear yield in one hybrid, but did not influence grain yield in both hybrids. The three types of products have different evaluation criterias. For example, kernel formation is obviously not important for baby corn production, but it is important for marketable husked green ears. On the other hand, poorly filled green ears are useless for green corn market, but could have value when the target final product be dry grain. In addition, the above-mentioned products are harvested at different times of the plant's cycle, which may also contribute to explain the differences between detasseling effects. Nevertheless, it is important to point out that the planting density used in the baby corn experiment was 3.6 times the density used in the other two experiments. Consequently, the beneficial effects of detasseling in the baby corn experiment support the observation from many authors that detasseling is interesting when the plants are under stress conditions, such as those that occur at high planting densities (Grogan, 1956; Hunter et al., 1969; Sangoi et al., 2006). At those densities, detasseling or male-sterility are factors that tend to increase plant tolerance to high planting densities, especially by reducing the rate of sterile plants (no ears). Detasseling benefits are less pronounced under edaphic-climatic and management conditions that favor high productivities, such as those used in this work in the experiments intended to evaluate green ear yield and grain yield (fertilization, irrigation, relatively small planting density, etc.) (Sangoi et al., 2006).

Therefore, it can be concluded that, in the three experiments, the hybrids did not differ from each other with regard to dry matter mass and number of tassel branches. In the experiment that evaluated baby corn yield, for both hybrids, detasseling caused increases in number and total weight of ears and in number and weight of marketable unhusked ears, but did not have an effect on the number and weight of marketable husked ears. Hybrid AG 1051 was superior in weight of marketable husked ears, but the hybrids did not differ for the other traits utilized to evaluate baby corn yield. In the green ear experiment, for both hybrids, detasseling did not have an effect on the total number and weight of ears and marketable unhusked ears and marketable husked ear weight, but reduced the number of marketable husked ears in hybrid AG 1051, without effects on these traits in the other hybrid. The hybrids did not differ with regard to total number of ears and number and weight of marketable unhusked ears, but AG 1051 was superior in other traits utilized to evaluate green corn yield. In the experiment that evaluated grain yield, detasseling did not impact grain yield (GY), number of ears ha-1 $(\mathrm{NE})$, number of kernels ear-1 $(\mathrm{KE})$ and 100-kernel weight (KW). Hybrid AG 1051 was superior for GY and KE, while hybrid BRS 2020 was superior for KW. There was no difference between hybrids for NE.

\section{REFERENCES}

AEKATASANAWAN C; CHOWCHONG S;
JAMPATONG S; BALLAC. 1994. Utilization of male sterility for baby corn improvement. Kasetsart Journal 28: 167-170.

ALMEIDA IPC; SILVA PSL; NEGREIROS MZ; BARBOSA, Z. 2005. Baby corn, green ear and grain yield of corn cultivars. Horticultura Brasileira 23: 960-964.

CARVALHO GS; VON PINHO RG; PEREIRA FILHO I. 2002. Efeito do tipo de cultivar, despendoamento das plantas e da época de semeadura na produção de minimilho. Revista Brasileira de Milho e Sorgo 1: 47-58.

CHENG PC; GREYSON RI; WALDEN DB. 1983. Organ initiation and the development of unisexual flowers in the tassel and ear of Zea mays. American Journal of Botany 70: 450-462.

CHENG PC; PAREDY DR. 1994. Morphology and development of the tassel and ear. In: FEELING M; WALBOT V. The maize handbook. New York, Springer-Verlag. 759p. Cap.3, p.37-47.

CLINE MG. 1997. Concepts and terminology of dominance apical. American Journal of Botany 84: 1064-1069.

DUN EA; FERGUSSON BJ; BEVERIDGE CA. 2006. Apical dominance and shoot branching. Divergent opinions or divergent mechanisms? Plant Physiology 142: 812-819.

DUNCAN WG; WILLIAMS WA; LOOMIS RS. 1967. Tassels and the productivity of maize. Crop Science 7: 37-39.

EMBRAPA. Centro Nacional de Pesquisa do Solo. 1999. Sistema brasileiro de classificação de solos. Brasília: Serviço de Produção de Informação. 412p.

FANCELLI AL; DOURADO-NETO D. 1997. Produção de milho. Guaíba: Agropecuária. $360 \mathrm{p}$.

FAO. 1988. Soil map of the world; revised legend. Rome: UNESCO.119p.

GALINAT WC; LIN BY. 1998. Baby corn: Production in Taiwan and future outlook for production in the United States. Economic Botany 42: 132-134.

GARCÍA DME. 1991. Regulación del crescimiento y desarollo in vitro de estructuras reproductivas en sorgo (Sorghum bicolor $L$. Moench). Montecillo, México: Colégio de Postgraduados. 111p. (Tese mestrado).

GERALDI IO; MIRANDA FILHO JB; VENCOVSKY R. 1985. Estimates of genetic parameters for tassel characters in maize (Zea mays L.) and breeding perspectives. Maydica 30: $1-14$

GROGAN CO. 1956. Detasseling responses in corn. Agronomy Journal 48: 247-249.

HARDOIM PR; SANDRI E; MALUF WR. 2002. Como fazer minimilho para aumentar a renda no meio rural. Lavras: UFLA. 4p. (Boletim Técnico de Hortaliças, 72).

HUANG S; CERNY RE; QI Y; BHAT D; AYDT CM; HANSON DD; MALLOY KP; NESS LA. 2003. Transgenic studies on the involvement of cytokinin and gibberellin in male development. Plant Physiology 131: 1270-1282.

HUNTER RB; DAYNARD TB; HUME DJ; TANNER JW; CURTIS JD; KANNEMBERG LW. 1969. Effect of tassel removal on grain 
yield of corn (Zea mays L.). Crop Science 9: 405-406.

KOMATUDAAS; SANTOS CM; SANTANADG; SOUZA MA; BRITO CH. 2006. Influência de métodos de despendoamento na produtividade e na qualidade das sementes de milho. Revista Brasileira de Milho e Sorgo 5: 359-368.

LEAL-LEÓN VM; LÓPEZ-PERALTA MC; GONZÁLEZ-HERNÁNDEZ, VA. 2002. In vitro development of young maize ears. Plant Cell, Tissue and Organ Culture 71: 133-139.

MOSTUT JJ; MARAIS JN. 1982. The effects of detasseling on the yield of irrigated maize. Crop Production 11: 163-167.

MOTAJCA. 2004. Caracterização fisica, química e mineralógica, como suporte para o manejo, dos principais solos explorados com a cultura do melão na Chapada do Apodi-RN. Fortaleza: UFC. 96p. (Tese mestrado).

PANDEY AK; PRAKESH VP; SINGH RD. 2000. Effect of rate of nitrogen and time of application on yield in economics of baby corn (Zea mays L.) Indian Journal of Agronomy 45: 338-343.

PEREIRA FILHO IA; CRUZ JC; ALVARENGA RC. 2005. Efeitos de densidade de semeadura, niveis de nitrogênio e despendoamento sobre a produção de minimilho. Sete Lagoas: EMBRAPA Milho e Sorgo. 5p. (Comunicado Técnico 119).

PINTHUS MJ; BELCHER AR. 1994. Maize topmost axillary shoot interference with lower ear development in vitro. Crop Science 34: 458-461.

RIBEIRO JÚNIOR JI. 2001. Análises estatísticas no SAEG. Viçosa: UFV. 301p.

SANDBERG MD; ORR AR. 1996. Early inflorescence and floral development in Zea mays land race Chapalote (Poaceae). American Journal of Botany 83: 1255-1265.

SANGOI L; GUIDOLIN AF; COIMBRA JLM; SILVA PRF. 2006. Resposta de híbridos de milho em diferentes épocas à população de plantas e ao despendoamento. Ciência Rural 36: 1367-1373.

SILVA PSL; SILVA KMB; SILVA NL; DINIZ FILHO ET; SANTOS MX. 1998. Rendimento de grãos verdes e secos de cultivares de milho I. Período 1985-90. Revista Ceres 45: 89-115.

SILVA PSL; SILVA PIB 2003. Parcelamento da adubação nitrogenada e rendimento de espigas verdes de milho. Horticultura Brasileira 21: 